\title{
Historical perspective of gastroesophageal reflux disease clinical treatment
}

\author{
Schlioma ZATERKA ${ }^{1}$, Sandra Beatriz MARION ${ }^{2}$, Fabiana ROVEDA ${ }^{3}$, \\ Marcos Antônio PERROTT| ${ }^{3}$ and Decio CHINZON ${ }^{4}$
}

Received 25/2/2019

Accepted 2/5/2019

\begin{abstract}
Background - Gastroesophageal reflux disease (GERD) is one of the most prevalent gastrointestinal diseases. GERD generates significant impairment in patients' quality of life and it is associated to relevant medical resources utilization. A better understanding of GERD pathophysiology in the past five decades has favored the evolution of therapeutic strategies from non-drug interventions and antacids to more efficacious and safer alternatives. Objective - To summarize data about the historical evolution of GERD management in Brazil, focusing on medical therapy and addressing evidence on efficacy and safety of drug classes currently recommended. Methods - A narrative review was conducted by systematizing information about discoveries on GERD pathophysiology. We also addressed efficacy and safety of medications currently used to reduce symptoms and improve endoscopic healing of esophageal lesions. A structured search on Pubmed was performed to identify systematic reviews and meta-analysis investigating GERD outcomes positively impacted by proton pump inhibitors (PPIs), the first choice of pharmacotherapy for the disease. Results - The chronological development of therapeutic measures for GERD in Brazil evolved from lifestyle interventions with relative poor effect on symptoms related to esophageal acid exposure, particularly heartburn, to effective and safe pharmacological interventions such as histamine H2-receptor antagonists and PPIs. In the present days, some drug classes play a minor role in disease management, namely prokinetics and antacids, due to their reduced efficacy and relevant safety concerns (particularly with prokinetics). The main challenge for prescribers and researchers seems to be finding long-acting acid suppressants strategies able to ameliorate patients' symptoms and quality of life, thereafter, reducing medical resource consumption. The dual delayed-release PPI dexlansoprazole seems to respond for some of the limitations other PPIs have. Conclusion - Recognizing the historical evolution of GERD management can help care providers to better understand therapeutic options for their patients, as well as focus on unmet needs that deserve further attention. PPIs are still the first choice therapy, with good evidence in favor of their efficacy, despite some safety concerns. However, as with any medical intervention, it is recommended to prescribe PPIs for patients with clear indication, using adequate dosing and monitoring for adverse events. HEADINGS - Gastroesophageal reflux. Drug therapy. Proton pump inhibitors. Histamine H2 antagonists. Antacids.
\end{abstract}

\section{INTRODUCTION}

Gastroesophageal reflux disease (GERD) is one of the most prevalent gastrointestinal conditions, resulting in significant impairment in patients' health-related quality of life and also relevant medical resources utilization ${ }^{(1-3)}$. GERD is the second leading diagnosis in the outpatient setting within the group of gastrointestinal, liver and pancreatic disorders in the United States representing over 7 million visits to health facilities in 2010 (Emergency Department visits accounted for 550,000 of them $)^{(3)}$. GERD is characterized by a chronic retrograde flow of gastric content to the esophagus or nearby structures (oropharynx and/or respiratory tract). It can cause a variety of clinical manifestations both esophageal and extra-esophageal, such as heartburn, acid regurgitation, chronic cough, asthma of difficult control, with or without evidence of tissue lesion ${ }^{(4,5)}$.

Epidemiological data have consistently demonstrated a rising GERD prevalence worldwide ${ }^{(6)}$. A recent systematic review with meta-analysis identified 108 studies assessing the global prevalence of GERD in 460,984 subjects. Prevalence ranged from $2.5 \%$ in China to $51.2 \%$ in Greece, but the pooled prevalence for studies that used a weekly frequency of heartburn or regurgitation as criteria was $13.3 \%(95 \% \text { CI } 12.0 \% \text { to } 14.6 \%)^{(7)}$. A Brazilian national wide population-based study reported that when reflux episodes occurred twice or more days a week GERD is observed in 7.3\% of the Brazilian population; and $11.9 \%$ of the population inquired related one episode of heartburn/regurgitation weekly ${ }^{(8)}$. Other smaller studies have observed frequencies of symptoms consistent with GERD as high as $20 \% \%^{(9,10)}$.

In the past century, GERD has transited from a rare diagnosis to one of the most frequently diagnosis in clinical practice among Western populations $\mathrm{s}^{(6,7,11)}$. Some risk factors are also becoming more frequent in general population, such as smoking, non-steroidal anti-inflammatory drug use and obesity ${ }^{(7)}$. Despite that, the wellestablished increment in prevalence is also explained by concrete advances in the understanding of disease features and in diagnostic methods. One of the major progresses was the recognition that a clear correlation between severity of troublesome reflux-induced

Declared conflict of interest of all authors: none

Disclosure of funding: no funding received

${ }^{1}$ Universidade de Campinas, Disciplina de Gastroenterologia, Campinas, SP, Brasil. ${ }^{2}$ Hospital Universitário Cajuru, Curitiba, PR, Brasil. ${ }^{3}$ Takeda Brasil Ringgold Standard Institution, São Paulo, SP, Brasil. ${ }^{4}$ Universidade de São Paulo, Faculdade de Medicina, Departamento de Gastroenterologia, São Paulo, SP, Brasil.

Corresponding author: Fabiana Roveda. E-mail: fabiana.roveda@takeda.com 
symptoms and presence or severity of endoscopically evident erosion is not observed for most patients ${ }^{(11)}$. Considering this distinction, GERD can be classified according to the presence or absence of erosions in nonerosive reflux disease (NERD) or erosive esophagitis $(\mathrm{EE})^{(6)}$.

The GERD pathophysiology is complex, multifactorial and associated with the interaction of several mechanisms. There is a predominant motor component involving the stomach, gastroesophageal junction, nervous structures, the esophagus and its sphincters. It is worth mentioning that despite the fact that acid suppressants are still core therapeutic options for GERD patients, assessments of stomach $\mathrm{pH}$ are usually similar between GERD and non GERD individuals ${ }^{(12)}$. The physiologic process of gastric acid secretion is controlled by a number of redundant second messenger pathways. They bind to specific receptors on basolateral surface of parietal cells of gastrin, acetylcholine, histamine and prostaglandins in order to be activated. The final process in the acid secretion pathway is the stimulation of the proton pump $\left(\mathrm{H}^{+}, \mathrm{K}^{+}\right.$-ATPase $)$to secrete hydrogen ions into the gastric lumen in exchange for potassium ions ${ }^{(13)}$. A better understanding of GERD pathophysiology has favored the emergence of novel therapeutic strategies, evolving from non-drug interventions and antacids to more efficacious and safer alternatives. In this context, the aim of this review is to provide a historical perspective of the medical therapy for GERD in Brazil. The progress from behavioral interventions to pharmacotherapy is addressed, focusing in both older drugs and more recent therapeutic options available to patients.

\section{METHODS}

A narrative review was conducted to systematize historical aspects of the GERD medical therapy evolution in Brazil. We used information abstracted from Brazilian and international studies, guidelines and consensus. Specifically for proton pump inhibitors (PPIs, the first choice in the management of GERD), a structure search for systematic reviews of efficacy and safety was conducted using a combination of MeSH controlled vocabulary and text words for 'omeprazole', 'lansoprazole', 'pantoprazole', 'esomeprazole', 'rabeprazole', 'dexlansoprazole', 'gastroesophageal reflux disease', 'non erosive reflux disease', 'endoscopy negative reflux disease' and 'systematic reviews' (FIGURE 1). Results are presented descriptively versus placebo or direct comparisons with other drugs within the PPI class.

\begin{tabular}{|c|c|c|}
\hline Database & Controlled vocabulary & Aim \\
\hline Pubmed & $\begin{array}{l}\text { ("omeprazole"[TIAB] OR “lansoprazole"[TIAB] } \\
\text { OR "pantoprazole"[TIAB] OR } \\
\text { "esomeprazole [TIAB] OR "rabeprazole"[TIAB] } \\
\text { OR “dexlansoprazole"[TIAB]) AND } \\
\text { ("gastroesophageal reflux disease"[TW] OR } \\
\text { "GERD"[TW] OR "non erosive reflux disease"[TW] } \\
\text { OR "NERD"[TW] OR "endoscopy negative reflux } \\
\text { disease"[TW] OR "ENRD"[TW]) AND ("systematic } \\
\text { reviews"[TW] OR "meta-analysis"[TW]) }\end{array}$ & $\begin{array}{l}\text { To identify relevant } \\
\text { systematic reviews and } \\
\text { meta-analysis of RCTs } \\
\text { for GERD or NERD } \\
\text { involving at least one } \\
\text { PPI arm }\end{array}$ \\
\hline
\end{tabular}

FIGURE 1. Search strategy for systematic reviews with or without metaanalysis assessing efficacy and safety of PPIs.

\section{RESULTS}

FIGURE 2 illustrates the historical evolution of GERD management in Brazil, following the worldwide introduction of non-pharmacological and pharmacological measures to improve symptom control and EE healing.

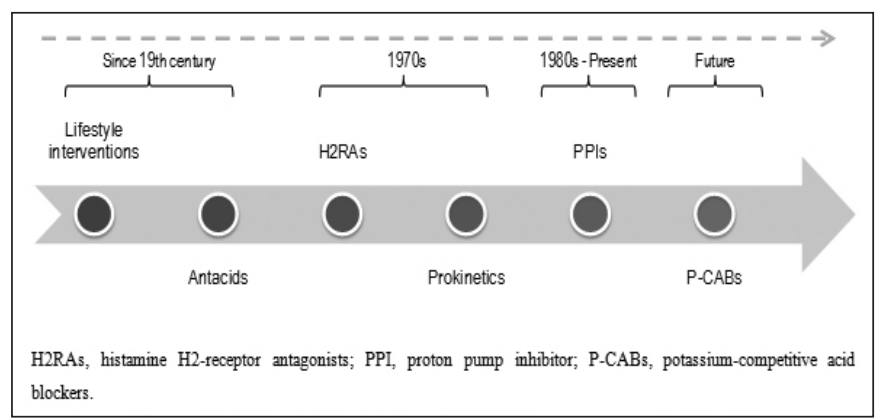

FIGURE 2. Historical evolution of GERD management in Brazil.

\section{Description of available treatments}

As shown in FIGURE 2, GERD management may involve lifestyle interventions, antacids, histamine receptor antagonists (H2Ras), prokinetics and proton pump inhibitors (PPIs).

Lifestyle modifications to control reflux symptoms were the first therapeutic measure established in the history of GERD management, when drug therapy and surgical interventions were still unknown or very rudimentary. These recommendations are based on the assumption that obesity, smoking, alcohol, body position and food intake interferes in structures that should prevent retrograde flow of gastric contents ${ }^{(14)}$.

Since GERD was explained initially as a condition associated with an excessive amount of gastric acid, the first pharmacotherapy employed to treat symptoms now recognized as associated with GERD was antacids ${ }^{(15)}$.

In the mid 1970's, medical discoveries around the mechanism of gastric acid secretion propelled the introduction of the first class acid suppression medication - histamine receptor antagonists ${ }^{(11)}$. Histamine was then considered a final common mediator for acid secretion and in 1972, Black et al. were able to synthesize an antagonist capable of inhibiting histamine receptors (burimamide followed by metiamide). In the following years, researchers could develop the H2RAs currently available in the Brazilian market. Further studies in both human and animal models observed that H2RAs inhibit acid secretion not only through histamine antagonism, but also through pathways involving carbachol and gastrin (secretagogues) $)^{(15)}$.

As previously mentioned, the pathophysiology of GERD involves motor alterations of the gastrointestinal tract, reason why prokinetic drugs were proposed alongside with antacids in the initial GERD pharmacotherapy era. In fact, 30\%-50\% of GERD patients present a delayed clearance time or a delayed gastric emptying phenomenon that prolongs esophageal acid exposure and allows retrograde flow of gastric contents ${ }^{(12)}$.

In the end of 1980's, GERD pharmacotherapy was greatly improved with incorporation of the acid pump inhibitor in the therapeutic armamentarium, represented initially by the PPI, omeprazole $^{(11)}$. The recognition of the gastric H,K-ATPase enzyme (or proton pump) as the final step of gastric acid secretion in the previous years allowed researchers to develop a more efficacious 
therapy for GERD patients. PPIs also act on gastric parietal cells through a different mechanism of H2RAs, inhibiting all acid secretion caused by various stimuli (not only histamine). Esophagus exposure to retrograde gastric acid contents is reduced, even though none of them are able to cure the disease ${ }^{(12)}$.

\section{Treatments summary of efficacy and safety \\ - Behavioral interventions and lifestyle advice}

Following the initial era of empirical observations only, several studies (both interventional and observational) investigated the effect of each proposed intervention. Three systematic reviews published between 2006 and 2016 synthesized these data observing conflicting results ${ }^{(14,16,17)}$.

Kaltenbach et al. $2006^{(14)}$ reviewed 16 studies (randomized clinical trials [RCTs] and non-randomized studies) that assessed GERD-related outcomes (change in symptoms, esophageal $\mathrm{pH}$ variables, or lower esophageal sphincter pressure). The authors concluded that weight loss interventions seem beneficial to improve $\mathrm{pH}$ profiles and symptoms. Also, they observed that head of bed elevation may contribute to prolong the time that esophageal $\mathrm{pH}$ was less than 4.0 (evidence gathered from observational studies). Dietary measures, smoking or alcohol cessation were not associated with improvement of GERD outcomes in the included studies. Festi et al. (2009) came to similar conclusions with the additional observation that moderate physical activity seems to play a role in reducing GERD manifestations, while extenuating or high intensity activity can worsen the condition in predisposed individuals ${ }^{(22)}$.

The most recent systematic review (Ness-Jensen et al., 2016) ${ }^{(17)}$ included 15 original studies, two systematic reviews (one about lifestyle intervention and one about conservative or surgical therapy for obesity among GERD patients) ${ }^{(14,18)}$ and also three guidelines (from the Canadian Association of Gastroenterology, American Gastroenterological Association and American College of Gastroenterology). Ness-Jensen et al., observed that time with esophageal acid exposure was effectively decreased with weight loss in two RCTs (from 5.6\% to $3.7 \%$ and from $8.0 \%$ to $5.5 \%$, respectively), in a similar manner as GERD symptoms in non-interventional prospective studies have done. A large prospective cohort observed that smoking cessation led to a reduction in reflux symptoms among non-obese patients (odds ratio [OR]: 5.67). A reduction in supine acid exposure was also observed in RCTs comparing late evening meals to early meals and head of bed elevation versus flat position ${ }^{(17)}$

Despite the relative dispute in the evidence about the benefit of some of the behavioral and lifestyle interventions to reduce GERD symptoms, they are widely used in clinical practice. For example, the $3 \mathrm{rd}$ Brazilian Consensus on GERD ${ }^{(19)}$ proposed the following recommendations: i) a $15 \mathrm{~cm}$ head-of-the-bed elevation; ii) reduction of the ingestion of the following foods depending on the individual correlation with symptoms: citric fruits, coffee, alcoholic, carbonated drinks, mint, peppermint, tomato, chocolate; iii) judicious use of drugs potentially linked with GERD symptoms: anticholinergics, theophylline, calcium channel blockers, and alendronate; iv) to avoid lying down for two hours after meals; v) to reduce the size of meals; vi) smoking cessation; vii) weight control in obese patients ${ }^{(4,5,20)}$.

\section{- Antacids}

Antacids were initially developed after an empirical observation that calcium carbonate $(\mathrm{CaCO} 3)$ was able to alleviate troublesome manifestations of gastric acid secretion by neutralizing intralumi- nal acidity ${ }^{(15)}$. Several other antacids were historically used with this purpose - sodium bicarbonate, aluminum hydroxide, and magnesium hydroxide, for instance. However, alginate-antacids (combinations of alginic acid with small doses of conventional antacids) are currently considered superior to antacids alone when recommended to short-term relief of mild infrequent symptoms or as rescue medication ${ }^{(6)}$. Nevertheless, the current knowledge about their effect has indicated that antacids remain active in the stomach for a very short period of time, providing poor therapeutic effect for most GERD patients. This observation and the still growing therapeutic arsenal for GERD and other gastric-acid related disorders have reserved a secondary role for antacids in the management of the disease.

\section{- Histamine H2-receptor antagonists (H2RAs)}

Clinical evidence accumulated since the introduction of this therapeutic strategy has shown that $\mathrm{H} 2 \mathrm{RAs}$ cimetidine, ranitidine, famotidine and nizatidine have a more prolonged action than antacids, even being recommended for short-term use or episodic symptoms associated with GERD ${ }^{(4,6)}$. Brazilian GERD Consensus Group, in its Guidelines for the diagnosis and management of GERD, stated that H2RAs may be beneficial in association with PPIs to reduce nocturnal symptoms of reflux and sleep disorders, although the level of evidence for this recommendation is weak. Therefore, there is a significant degree of uncertainty about the efficacy of H2RAs at night in association with regular therapy with $\operatorname{PPI}^{(20)}$

The currently reduced importance of H2RAs in the management of GERD is mostly attributed to a solid body of evidence showing that they are less efficacious than PPIs, the first choice for GERD symptoms control. A 2013 Cochrane Systematic Review including 34 trials (1314 participants) that investigated short-term PPIs or H2RAs for GERD and NERD identified a better efficacy profile for PPIs versus placebo as compared to H2RAs (also versus placebo). The relative risk in placebo-controlled trials of PPI and H2RAs for GERD was 0.37 (95\% confidence interval 0.32 to 0.44 , versus placebo) and 0.77 (95\% CI 0.60 to 0.99 , versus placebo), respectively. PPIs directly compared to H2RAs were also more effective (RR $0.66,95 \%$ CI 0.60 to 0.73 ). The analysis for NERD showed that the RR for heartburn remission versus placebo for PPI was 0.71 (95\% CI 0.65 to 0.78 ) and for H2RA was $0.84(95 \%$ CI 0.74 to 0.95 ). The RR for PPI versus H2RA in NERD was 0.78 $(95 \% \text { CI } 0.62 \text { to } 0.97)^{(21)}$.

\section{- Prokinetics}

The rationale was reasonable at the time of prokinetics' first introduction, but results from clinical trials could not identify a clear efficacy pattern for prokinetics ${ }^{(21)}$.

A Cochrane Systematic Review investigated the comparative efficacy of prokinetics versus H2RAs and PPIs and showed less favorable outcomes in both comparisons. In patients with GERD, the relative risk for remission of heartburn symptoms was 0.86 (95\% confidence interval 0.73 to 1.01 ) versus placebo, with a nonsignificant statistical difference, and the direct comparison versus PPIs clearly favored the comparator. One RCT showed that PPIs are also consistently superior to prokinetics in reducing heartburn in NERD patients ${ }^{(21)}$.

Besides efficacy results, safety concerns have decreased substantially the use of prokinetics. Cisapride have been withdrawn from the market worldwide due to relevant cardiac adverse events. 
Furthermore, the still available prokinetics, metoclopramide and domperidone, even used in a large scale in some countries, have poor proven efficacy. Metoclopramide is not recommended due to neurological risks, while domperidone is not recommended due to cardiovascular risks, in higher doses or prolonged use ${ }^{(6,12)}$.

\section{- Proton pump inhibitors}

As previously mentioned, the efficacy of PPIs is well-established as superior to H2RA's and other classes of GERD pharmacotherapy's efficacy, mostly due to their more prolonged action and the absence of resistance ${ }^{(21)}$. According to international guidelines, a patient diagnosed with GERD (by presenting troublesome symptoms twice weekly or more) is suitable for empirical therapy with an acid inhibitor without the need for confirmation through endoscopy, preferentially a PPI (other drugs should be considered only in contexts where they are not available $)^{(6,22-24)}$. Besides GERD (and NERD), PPIs are also recommended for esophagitis, peptic ulcer disease, prevention of nonsteroidal anti-inflammatory drugs associated ulcers, Zollinger-Ellison syndrome, functional dyspepsia and Helicobacter pylori (in combination with antibiotics). Thereafter, since its introduction, PPIs have become one of the most prescribed medication classes in the primary care setting ${ }^{(11)}$.

The PPIs currently available in Brazil are omeprazole, lansoprazole, pantoprazole, esomeprazole, rabeprazole, and the most recently launched dexlansoprazole ${ }^{(25-30)}$. Efficacy and safety of all 6 PPIs were assessed in a network meta-analysis conducted by Chen et al., 2016. The authors evaluated the available evidence about symptom relief and rate of adverse events (AEs) of different PPIs in different dosing schemes in treating patients with NERD. Overall, in terms of symptomatic relief rate, compared with placebo, all interventions except rabeprazole $5 \mathrm{mg}$ demonstrated clinical benefit. Within direct comparison with active drugs, omeprazole $20 \mathrm{mg}$ was associated with a higher rate of symptom relief versus omeprazole $10 \mathrm{mg}$ (OR: $1.89,95 \% \mathrm{CI}: 1.34$ to 2.67 ) and rabeprazole $5 \mathrm{mg}$ (OR: $2.51,95 \%$ CI: 1.16 to 5.42 ). Dexlansoprazole $30 \mathrm{mg}$ significantly improved the outcome compared with rabeprazole $5 \mathrm{mg}$ group (OR: $2.64,95 \%$ CI: 1.08 to 6.43 ). For the rate of adverse events, a significant difference among all interventions was not observed, indicating a similar safety profile. As usually performed in network meta-analysis, Chen et al. (2016) also ranked the PPIs for the investigated outcomes. For symptom relief, dexlansoprazole $30 \mathrm{mg}$ ranked the first among all comparators (other PPIs and placebo), while for the rate of AEs, omeprazole $20 \mathrm{mg}$ presented the lowest incidence and lansoprazole $30 \mathrm{mg}$ the highest ${ }^{(31)}$.

The systematic review conducted by Li et al. (2017) aimed at identifying relevant studies on PPIs for EE using a network metaanalysis (NMA) approach ${ }^{(32)}$. Authors included 25 RCTs enrolling adults with EE receiving PPIs continuously for at least four weeks, using endoscopic healing rates at four and eight weeks as efficacy outcome and discontinuation rates for safety. All PPIs included (dexlansoprazole $60 \mathrm{mg}$, esomeprazole $20 \mathrm{mg}$, esomeprazole $40 \mathrm{mg}$, lansoprazole $30 \mathrm{mg}$, omeprazole $20 \mathrm{mg}$, pantoprazole $40 \mathrm{mg}$, rabeprazole $20 \mathrm{mg}$ ) were statistically superior to placebo in the efficacy evaluation. Comparative analysis versus omeprazole 20 $\mathrm{mg}$ indicated that esomeprazole $40 \mathrm{mg}$ improved healing rates at 4 and 8 weeks (OR of 1.46 and 1.58, respectively, both statistically significant). Versus lansoprazole $30 \mathrm{mg}$, esomeprazole $40 \mathrm{mg}$ was also more effective at four and eight weeks (OR of 1.30 and 1.29, statistically significant). Only 1 RCT for dexlansoprazole $60 \mathrm{mg}$ was included in the Li et al. (2017) review and provided data only for endoscopic healing rate at eight weeks and the acceptability analysis (in which the drug presented significantly higher all-cause discontinuation rate than comparators).

In the dexlansoprazole clinical development program, RCTs reported non-inferiority of dexlansoprazole $60 \mathrm{mg}$ and $90 \mathrm{mg}$ to lanzoprazole $30 \mathrm{mg}$ after eight weeks in healing of erosive esophagitis, providing higher healing rates in total sample (until six percentage points) and of dexlansoprazole $90 \mathrm{mg}$ to lansoprazole $30 \mathrm{mg}$ in healing of moderate to severe EE (eight percentage points). Considering patients with baseline grades $\mathrm{C}$ or D erosive esophagitis, healing rates are still higher, until 14 percentage points. Regarding assessment of heartburn relief, dexlansoprazole and lansoprazole demonstrated a similar pattern of efficacy ${ }^{(33)}$.

Dexlansoprazole was launched in Brazil in 2017 for GERD, the first PPI with a dual delayed-release formulation. Dexlansoprazole has two distinct drug release moments to prolong plasma concentration time and duration of acid suppression, which is a major challenge for GERD management and a therapeutic gap for the PPI class ${ }^{(34)}$. Besides the evidence previously mentioned for the medication, Wu et al., 2013 ${ }^{(35)}$, performed an indirect comparison of dexlansoprazole $30 \mathrm{mg}$ versus esomeprazole $20 \mathrm{mg}$ or $40 \mathrm{mg}$, showing significant differences in heartburn control in NERD patients at four weeks (dexlansoprazole $30 \mathrm{mg}$ versus esomeprazole $20 \mathrm{mg}$ or $40 \mathrm{mg}$ - RR: 2.01 ; $95 \%$ CI: 1.15 to 3.51 and RR: 2.17 ; 95\% CI: 1.39 to 3.38 ). Comparisons for EE were not able to verify significant differences between the PPIs.

Safety concerns accompanied the evolution of PPI therapy since its introduction in the 1980s with several reviews being published to address risk of hazards allegedly associated with long term or inappropriate PPI use ${ }^{(36-42)}$. Chen et al., (2012), summarized the available evidence regarding three specific concerns raised about PPI therapy in the past few years: drug-drug interaction with clopidogrel, increased risk of fractures, and hypomagnesemia ${ }^{(36)}$. Despite in vitro evidence of interaction between some PPIs and clopidogrel, the authors identified one RCT comparing clopidogrel alone versus clopidogrel + omeprazole. In this study, the rate of cardiovascular events was not increased and a reduction in gastrointestinal adverse events was found in the combination group. In terms of fracture risk, the quality of the available evidence was considered poor, but authors stated that PPI use could be a weak predisposing factor for hip or vertebral fractures due to the relationship with the decrease in the absorption of folates, riboflavin and vitamin B12, with a high degree of uncertainty. PPI-associated hypomagnesemia data based on high quality evidence was also unavailable, preventing authors from clearly identify a risk directly linked to PPI use. However, the use of retrospective data can add several types of bias, highlighting the need of further investigation of the outcome.

Moayyedi et al., (2012), also reviewed interventional and observational studies that assessed some risks frequently attributed to PPIs ${ }^{(39)}$. Besides the ones already addressed by Chen et al. $2012^{(36)}$, the authors also investigated a potential link with increased risk of pneumonia and infective diarrhea, including Clostridium difficile-associated diarrhea. They concluded that most of these associations are modest with a high risk of bias due to confounding factors. Regarding their findings, RCT data do not support an increased incidence of pneumonia in patients 
treated with PPIs. However, observational studies have demonstrated a stronger association with enteric infection, probably due to reduced protection against bacteria caused by decreased gastric acidity. Schneider et al., (2016), also investigated if long-acting pantoprazole or other PPIs use can lead to a higher probability of being diagnosed with gastric cancer or other cancers, but no evidence was found to support this allegation ${ }^{(41)}$. Yadlapati et al. (2017), described in a review that the occurrence of Clostridium difficile-associated diarrhea has weak association with the prolonged PPI use, once this association have been demonstrated through an observational study ${ }^{(37)}$.

These data reinforce the efficacy and safety of PPIs and justify their position as first choice medication to treat acid-related gastroesophageal disorders. PPI treatment failure is rare but may be related to wrong diagnosis, noncompliance or poor adherence, inadequate dosing time or inadequate dosing, psychological comorbidity or other concomitant conditions ${ }^{(6,43)}$. Those aspects need to be addressed before considering a GERD patient as refractory, once therapeutic options for those patients are currently scarce ${ }^{(44)}$.

\section{Future options}

Despite a well-established pharmacotherapy rationale with efficacious and safe drugs, GERD management still has some areas for improvement, particularly longer action duration. A third-generation antisecretory drug class known as potassiumcompetitive acid blockers (P-CABs) has emerged in the last few years in response to some of these limitations. The P-CABs inhibit gastric $\mathrm{H}+, \mathrm{K}+$-ATPase in a $\mathrm{K}+$ competitive and reversible manner. In the initial clinical development phases, they showed rapid onset of action, larger accumulation in gastric glands with slower clearance than PPIs, resulting in longer duration of antisecretory effect $^{(45,46)}$. At this time, none of the P-CABs are available in Brazil.

\section{DISCUSSION}

Historically, the initial management of GERD was focused on lifestyle and behavioral interventions, such as avoiding specific foods, adopting favorable eating habits or head of bed elevation, and the prescription of antacids. Further discoveries about the pathophysiology of GERD and the mechanisms of gastric acid secretion allowed researchers to develop acid suppression therapies targeting firstly histamine receptors (histamine H2-receptor antagonists) and afterwards H,K-ATPase enzyme (proton pump inhibitors). Currently, national and international guidelines recommend PPIs as first choice in GERD management, but the other classes still have their place in specific clinical scenarios (mainly short term relief or mild episodic symptoms). In Brazil, six PPIs are currently available (omeprazole, lansoprazole, pantoprazole, esomeprazole, rabeprazole, and dexlansoprazole), all of them with satisfactory evidence about efficacy and safety based on randomized clinical trials, systematic reviews with meta-analysis and also long-term observational studies. Dexlansoprazole is the most recent PPI option for GERD Brazilian patients, with an innovative release technology, producing longer duration of antisecretory effect during the day. Future perspectives to enhance the therapeutic armamentarium seem to be focused on P-CABs, still not available in Brazil but with promising results.

\section{CONCLUSION}

GERD is one of the most frequent diagnoses in clinical practice with increasing prevalence worldwide. Recognizing the historical evolution of GERD management can help care providers to better understand therapeutic options for their patients, as well as focus on unmet needs that deserve further attention. PPIs are still the first choice for GERD or NERD patients, with good evidence in favor of their efficacy, despite some concerns about safety. As with any medical intervention, it is recommended to prescribe PPIs for patients with clear indication, using adequate dosing and monitoring for adverse events.

\section{AKNOWLEDGEMENTS}

This work was supported by Takeda Pharmaceutical Company Limited. We thank SENSE Company Brazil for editorial support in developing drafts of this manuscript. The authors were responsible for critical revisions of the manuscript for important intellectual content.

\section{Authors' contribution}

Zaterka S: substantial contributions to the concept and design, acquisition of data; critically revised the manuscript for important intellectual content; final approval of the version to be published; agreed to be accountable for all aspects of the work in ensuring that questions related to accuracy or integrity are appropriately investigated and resolved.

Marion SB: substantial contributions to the concept and design, acquisition of data; critically revised the manuscript for important intellectual content; final approval of the version to be published; agreed to be accountable for all aspects of the work in ensuring that questions related to accuracy or integrity are appropriately investigated and resolved.

Roveda F: analysis and interpretation of data; critically revised the manuscript for important intellectual content; final approval of the version to be published; agreed to be accountable for all aspects of the work in ensuring that questions related to accuracy or integrity are appropriately investigated and resolved.

Perrotti MA: analysis and interpretation of data; critically revised the manuscript for important intellectual content; final approval of the version to be published; agreed to be accountable for all aspects of the work in ensuring that questions related to accuracy or integrity are appropriately investigated and resolved.

Chinzon D: substantial contributions to the concept and design, acquisition of data; critically revised the manuscript for important intellectual content; final approval of the version to be published; agreed to be accountable for all aspects of the work in ensuring that questions related to accuracy or integrity are appropriately investigated and resolved.

\section{Orcid}

Schlioma Zaterka. Orcid: 0000-0002-2260-9146.

Sandra Beatriz Marion. Orcid: 0000-0002-4429-0447.

Fabiana Roveda. Orcid: 0000-0003-2898-717X.

Marcos Antônio Perrotti. Orcid: 0000-0003-4842-1552.

Decio Chinzon. Orcid: 0000-0003-3030-6687. 
Zaterka S, Marion SB, Roveda F, Perrotti MA, Chinzon D. Perspectiva histórica do tratamento clínico da doença do refluxo gastroesofágico. Arq Gastroenterol. 2019;56(2):202-8.

RESUMO - Contexto - A doença do refluxo gastroesofágico (DRGE) é uma das doenças gastrointestinais mais prevalentes, resultando em limitações significativas na qualidade de vida dos pacientes e, também, relevante utilização de recursos médicos. Um melhor entendimento da fisiopatologia da doença nas últimas cinco décadas tem favorecido a evolução das estratégias de tratamento, desde intervenções não farmacológicas e antiácidos, a alternativas mais eficazes e seguras. Objetivo - Resumir os dados sobre a evolução histórica do manejo da DRGE no Brasil, focando na terapia medicamentosa e abordando evidências sobre a eficácia e segurança de classes medicamentosas atualmente recomendadas. Métodos - Uma revisão narrativa foi conduzida para sistematizar informações sobre descobertas na fisiopatologia da DRGE e, também, sobre a eficácia e segurança de medicamentos utilizados atualmente para reduzir os sintomas e melhorar a cicatrização endoscópica de lesões esofágicas. Uma busca estruturada na base de dados Pubmed foi realizada para identificar revisões sistemáticas e metanálises que investigassem desfechos da doença impactados positivamente pelos inibidores da bomba de prótons (IBPs), a primeira escolha farmacológica para a doença. Resultados - O desenvolvimento cronológico das medidas terapêuticas para a DRGE no Brasil evoluiu de modificações no estilo de vida que demonstraram relativamente pouco efeito sobre os sintomas relacionados à exposição esofágico ao ácido, particularmente a azia, a intervenções farmacológicas eficazes e seguras como os anti-histamínicos H2 e os IBPs. Atualmente, algumas classes de medicamentos exercem um papel menor no manejo da doença, procinéticos e antiácidos por exemplo, devido à sua eficácia reduzida e a preocupações relevantes quanto a segurança (particularmente com os procinéticos). O principal desafio para os prescritores e pesquisadores parece ser encontrar estratégias supressoras de ácidos de longa duração capazes de melhorar os sintomas e a qualidade de vida dos pacientes, reduzindo assim o consumo de recursos médicos. O dexlansoprazol, um IBP de liberação retardada dupla, parece responder a algumas limitações que outros IBPs têm. Conclusão - O reconhecimento da evolução histórica do manejo da DRGE pode auxiliar aos profissionais assistentes a melhor entender as opções terapêuticas para seus pacientes, assim como focar em necessidades não atendidas que necessitem de maior atenção. IBPs ainda são a terapia de escolha inicial, com boas evidências a favor de sua eficácia, apesar algumas questões acerca da segurança de seu uso. No entanto, assim como para qualquer intervenção medicamentosa, é recomendada a prescrição dos IBPs para pacientes com indicação clara, utilizando doses adequadas e monitorando a ocorrência de eventos adversos.

DESCRITORES - Refluxo gastroesofágico. Tratamento farmacológico. Inibidores da bomba de prótons. Antagonistas dos receptores histamínicos H2. Antiácidos.

\section{REFERENCES}

1. Bruley Des Varannes S, Marek L, Humeau B, Lecasble M, Colin R. Gastroesophageal reflux disease in primary care. Prevalence, epidemiology and Quality of Life of patients. Gastroenterol Clin Biol. 2006;30:364-70.

2. Eslick GD, Talley NJ. Gastroesophageal reflux disease (GERD): risk factors, and impact on quality of life-a population-based study. J Clin Gastroenterol. 2009;43:111-7.

3. Peery AF, Crockett SD, Barritt AS, Dellon ES, Eluri S, Gangarosa LM, et al. Burden of Gastrointestinal, Liver, and Pancreatic Diseases in the United States. Gastroenterology. 2015;149:1731-41.e3.

4. Federação Brasileira de Gastroenterologia, Sociedade Brasileira de Endoscopia Digestiva, Colégio Brasileiro de Cirurgia Digestiva, Sociedade Brasileira de Pneumologia e Tisiologia. Doença do Refluxo Gastroesofágico: Diagnóstico. Diretrizes Clínicas na Saúde Suplementar. 2011. 1-6 p.

5. Federação Brasileira de Gastroenterologia. Projeto Diretrizes - Refluxo Gastroesofágico: Diagnóstico e Tratamento. Rev AMRIGS. 2006;50(3):251-63.

6. Hunt R, Chen M, Melo AC, Ford A, Lazebnik L, Lizarzabal M, et al. Global Perspective on Gastroesophageal Reflux Disease. World Gastroenterol Organ Glob Guidel GERD. 2015;(October).

7. Eusebi LH, Ratnakumaran R, Yuan Y, Solaymani-Dodaran M, Bazzoli F, Ford AC. Global prevalence of, and risk factors for, gastro-oesophageal reflux symptoms: a meta-analysis. Gut. 2018;67:430-40.

8. Moraes-Filho JPP, Chinzon D, Eisig JN, Hashimoto CL, Zaterka S. Prevalence of heartburn and gastroesophageal reflux disease in the urban Brazilian population. Arq Gastroenterol. 2005;42:122-7.

9. Pereira-Lima J, Blaya C, Rynkowski CB, Althaus-Júnior W, Frey BN, Prati C, et al. Prevalência da doença do refluxo gastroesofágico: estudo populacional em Porto Alegre, Rio Grande do Sul. GED Gastroenterol Endosc Dig. 2000;19:73-8.

10. do Rosário Dias de Oliveira Latorre M, Medeiros da Silva A, Chinzon D, Eisig JN, Dias-Bastos TRP. Epidemiology of upper gastrointestinal symptoms in Brazil (EpiGastro): a population-based study according to sex and age group. World $\mathbf{J}$ Gastroenterol. 2014;20:17388-98.

11. Dent J. From 1906 to 2006 - a century of major evolution of understanding of gastrooesophageal reflux disease. Aliment Pharmacol Ther. 2006;24:1269-81.

12. Savarino E, Zentilin P, Marabotto E, Bodini G, Della Coletta M, Frazzoni M, et al. A review of pharmacotherapy for treating gastroesophageal reflux disease (GERD). Expert Opin Pharmacother. 2017;18:1333-43.
13. Scarpignato C, Pelosini I, Di Mario F. Acid Suppression Therapy: Where Do We Go from Here? Dig Dis. 2006;24:11-46.

14. Kaltenbach T, Crockett S, Gerson LB. Are Lifestyle Measures Effective in Patients With Gastroesophageal Reflux Disease? Arch Intern Med. 2006;166:965.

15. Aihara T, Nakamura E, Amagase K, Tomita K, Fujishita T, Furutani K, et al. Pharmacological control of gastric acid secretion for the treatment of acid-related peptic disease: past, present, and future. Pharmacol Ther. 2003;98:109-27.

16. Festi D, Scaioli E, Baldi F, Vestito A, Pasqui F, Di Biase AR, et al. Body weight, lifestyle, dietary habits and gastroesophageal reflux disease. World J Gastroenterol. 2009; 15:1690-701.

17. Ness-Jensen E, Hveem K, El-Serag H, Lagergren J. Lifestyle Intervention in Gastroesophageal Reflux Disease. Clin Gastroenterol Hepatol. 2016;14:175-82.e1-3.

18. De Groot NL, Burgerhart JS, Van de Meeberg PC, De Vries DR, Smout AJPM, Siersema PD. Systematic review: the effects of conservative and surgical treatment for obesity on gastro-oesophageal reflux disease. Aliment Pharmacol Ther. 2009;30:1091-102.

19. Henry MACA. Diagnóstico e tratamento da doença do refluxo gastroesofágico. ABCD Arq Bras Cir Dig. 2014;27:210-5.

20. Moraes-Filho JPP, Navarro-Rodriguez T, Barbuti R, Eisig J, Chinzon D, Bernardo W. Guidelines for the diagnosis and management of gastroesophageal reflux disease: an evidence-based consensus. Arq Gastroenterol. 2010;47:99-115.

21. Sigterman KE, van Pinxteren B, Bonis PA, Lau J, Numans ME. Short-term treatment with proton pump inhibitors, H2-receptor antagonists and prokinetics for gastro-oesophageal reflux disease-like symptoms and endoscopy negative reflux disease. Cochrane Database Syst Rev. 2013;(5):CD002095.

22. Lichtenstein DR, Cash BD, Davila R, Baron TH, Adler DG, Anderson MA, et al. Role of endoscopy in the management of GERD. Gastrointest Endosc. 2007;66:219-24

23. Katz PO, Gerson LB, Vela MF. Guidelines for the Diagnosis and Management of Gastroesophageal Reflux Disease. Am J Gastroenterol. 2013;108:308-28.

24. Shaheen NJ, Weinberg DS, Denberg TD, Chou R, Qaseem A, Shekelle P, et al. Upper Endoscopy for Gastroesophageal Reflux Disease: Best Practice Advice From the Clinical Guidelines Committee of the American College of Physicians. Ann Intern Med. 2012;157:808.

25. Brasil. Ministério da Saúde. Portaria n ${ }^{\circ} 55$, de 05 de dezembro de 1990: omeprazol. Diário Oficial da União. Brasília: Imprensa Nacional; 1990. 
26. Brasil. Ministério da Sáude. Portaria no 22 de 1o de março de 1994: lansoprazol Diário Oficial da União. Brasília: Imprensa Nacional; 1994.

27. Brasil. Ministério da Saúde. Portaria no 45, de 6 de abril de 1995: pantoprazol. Diário Oficial da União. Brasília: Imprensa Nacional; 1995.

28. Brasil. Ministério da Saúde. Portaria no 342 de 15 de abril de 1999: rabeprazol. Diário do Senado Federal. Brasília: Imprensa Nacional; 1999.

29. Brasil. Ministério da Saúde. Resolução-RE no 512/MS/ANVS, de 28 de dezembro de 2000: esomeprazol. Diário Oficial da União. Brasília: Imprensa Nacional; 2000 .

30. Brasil. Ministério da Saúde. Resolução - RE no 317, de 27 de janeiro de 2012 Registro de medicamento novo: dexlansoprazol. Diário Oficial da União. Brasília: Imprensa Nacional; 2012.

31. Chen L, Chen Y, Li B. The efficacy and safety of proton-pump inhibitors in treating patients with non-erosive reflux disease: a network meta-analysis. Sci Rep. 2016;6:32126.

32. Li M-J, Li Q, Sun M, Liu L-Q. Comparative effectiveness and acceptability of the FDA-licensed proton pump inhibitors for erosive esophagitis: A PRISMA-compliant network meta-analysis. Medicine (Baltimore). 2017;96:e8120.

33. Sharma P, Shaheen NJ, Perez MC, Pilmer BL, Lee M, Atkinson SN, et al. Clinical trials: Healing of erosive oesophagitis with dexlansoprazole MR, a proton pump inhibitor with a novel dual delayed-release formulation - Results from two randomized controlled studies. Aliment Pharmacol Ther. 2009;29:731-41.

34. Fass R, Johnson DA, Orr WC, Han C, Mody R, Stern KN, et al. The Effect of Dexlansoprazole MR on Nocturnal Heartburn and GERD-Related Sleep Disturbances in Patients With Symptomatic GERD. Am J Gastroenterol. 2011;106:421-31.

35. Wu MS, Tan SC, Xiong T. Indirect comparison of randomised controlled trials: comparative efficacy of dexlansoprazole vs. esomeprazole in the treatment of gastro-oesophageal reflux disease. Aliment Pharmacol Ther. 2013;38:190-201.
36. Chen J, Yuan YC, Leontiadis GI, Howden CW. Recent safety concerns with proton pump inhibitors. J Clin Gastroenterol. 2012;46:93-114.

37. Yadlapati R, Kahrilas PJ. When is proton pump inhibitor use appropriate? BMC Med. 2017;15:1-4.

38. Choudhry U, Boyce HW, Coppola D. Proton pump inhibitor-associated gastric polyps: A retrospective analysis of their frequency, and endoscopic, histologic, and ultrastructural characteristics. Am J Clin Pathol. 1998;110:615-21.

39. Moayyedi P, Leontiadis GI. The risks of PPI therapy. Nat Rev Gastroenterol Hepatol. 2012;9:132-9.

40. Zink DA, Pohlman M, Barnes M, Cannon ME. Long-term use of acid suppression started inappropriately during hospitalization. Aliment Pharmacol Ther 2005;21:1203-9.

41. Schneider JL, Kolitsopoulos F, Corley DA. Risk of gastric cancer, gastrointestinal cancers and other cancers: a comparison of treatment with pantoprazole and other proton pump inhibitors. Aliment Pharmacol Ther. 2016;43:73-82.

42. Antoniou T, Macdonald EM, Hollands S, Gomes T, Mamdani MM, Garg AX, et al. Proton pump inhibitors and the risk of acute kidney injury in older patients: a population-based cohort study. C Open. 2015;3:E166-71.

43. Dal-Paz K, Moraes-Filho JP, Navarro-Rodriguez T, Eisig JN, Barbuti R, Quigley EMM. Low levels of adherence with proton pump inhibitor therapy contribute to therapeutic failure in gastroesophageal reflux disease. Dis Esophagus. 2012;25: 107-13.

44. Moraes-Filho JPP. Refractory gastroesophageal reflux disease. Arq Gastroenterol 2012;49:296-301.

45. Satoh H. Discovery and Development of Proton Pump Inhibitors. In Karger Publishers; 2013. p. 1-17.

46. Inatomi N, Matsukawa J, Sakurai Y, Otake K. Potassium-competitive acid blockers: Advanced therapeutic option for acid-related diseases. Pharmacol Ther. 2016;168:12-22 